DOI: $10.14720 /$ aas.2016.107.2.03

Agrovoc descriptors: Artemisia, drought, drought stress, drought resistance, salicylic acid, plant growth substances, in vitro experimentation, plant physiology, growth, phenylalanine ammonia-lyase

Agris category code: F60, F62

\title{
The impact of salicylic acid on some physiological responses of Artemisia aucheri Boiss. under in vitro drought stress
}

\author{
Jalil ABBASPOUR ${ }^{1}$, and Aliakbar EHSANPOUR ${ }^{2}$
}

Received October 19, 2015; accepted March 04, 2016.

Delo je prispelo 19. oktobra 2015, sprejeto 04. marca 2016.

\begin{abstract}
Salicylic acid (SA) is an important plant regulator which is involved in growth, development, and response to stress. This study was aimed to evaluate some physiological and biochemical responses of Artemisia aucheri Boiss. under drought stress after exogenous SA treatment. Experiment was performed in vitro. Polyethylene glycol (PEG/6000) with 0,2 and $4 \%(\mathrm{w} / \mathrm{v})$ was used in MS medium to simulate drought stress and different concentrations of SA $(0,0.01$ and $0.1 \mathrm{mM})$ were added. After four weeks, SA alleviated the negative effects of PEG on dry and fresh mass as well as chlorophyll and carotenoid contents. Under drought stress, application of SA decreased storage polysaccharides and increased soluble carbohydrates respectively. Although PEG had no significant effect on flavonoid content, it increased significantly anthocyanin and total phenol content, total antioxidant capacity, PAL (phenylalanine ammonia-lyase) and TAL (tyrosine ammonia-lyase) activity and SA treatment improved these parameters significantly. According to the current data, it was concluded that SA increased drought tolerance of Artemisia aucheri by increasing biosynthesis of phenolic compounds, improvement of TAL and PAL activity as well as also by increased content of soluble carbohydrates.
\end{abstract}

Key words: Artemisia aucheri Boiss., salicylic acid, drought stress; polyethylene glycol, growth, phenylalanine ammonia-lyase, tyrosine ammonia-lyase

\section{IZVLEČEK}

\author{
VPLIV SALICILNE KISLINE NA NEKATERE \\ FIZIOLOŠKE ODZIVE VRSTE PELINA (Artemisia \\ aucheri Boiss.) NA SUŠNI STRES V IN VITRO \\ RAZMERAH
}

Salicilna kislina je pomemben rastlinski hormon, ki je vključen v uravnavanje rasti, razvoja in odziva na stres. Cilj raziskave je bil ovrednotiti nekatere fiziološke in biokemične odzive vrste pelina Artemisia aucheri Boiss. v sušnem stresu po zunanjem dodajanju salicilne kisline. Poskus je potekal in vitro, v MS gojišču (Murashige and Skoog., 1962) z dodatkom polietilen glikola (PEG/6000, 0, 2 in $4 \%(\mathrm{w} / \mathrm{v}))$ za simulacijo sušnega stresa in dvema različnima koncentracijama salicilne kisline (SA) (0, 0.01 in $0.1 \mathrm{mM})$. Po štirih tednih je salicilna kislina zmanjšala negativne učinke polietilen glikola na suho in svežo maso kot tudi na vsebnosti klorofila in karotenoidov. $\mathrm{V}$ sušnem stresu je uporaba salicilne kisline zmanjšala vsebnost založnih polisaharidov in povečala vsebnost topnih ogljikovih hidratov. Čeprav polietilen glikol ni imel značilnega učinka na vsebnostn flavonoidov je značilno povečal vsebnost antocianinov, celokupnih fenolov, celokupno antioksidacijsko sposobnost, aktivnost PAL (fenilalanin amonium-liaza) in TAL (tirozin amonium-liaza), obravnavanje s salicilno kislino je te parametre značilno izboljšalo. Glede na te rezultate je bilo zaključeno, da salicilna kislina povečuje strpnost na sušo pri vrsti Artemisia aucheri s povečanjem biosinteze fenolnih snovi, $\mathrm{z}$ izboljšanjem aktivnosti TAL in PAL kot tudi s povečanjem vsebnosti topnih ogljikovih hidratov.

Ključne besede: Artemisia aucheri Boiss., salicilna kislina, sušni stres; polietilen glikol, rast, fenilalanin amonium-liaza, tirozin amoniium-liaza

\footnotetext{
$\mathrm{PhD}$ student, Department of Biology, Faculty of Science, University of Isfahan, Isfahan, Iran

Prof., Department of Biology, Faculty of Science, University of Isfahan, Isfahan, Iran; corresponding author: ehsanpou@sci.ui.ac.ir
} 


\section{INTRODUCTION}

The genus Artemisia belongs to Asteraceae family. There are 500 species of Artemisia in Asia, Europe and North America. Thirty four species of this family are known as wild spicies all over Iran. One of these species is Artemisia aucheri Boiss which has limited ecological distribution, it is endemic to mountainous areas of Iran and surroundings (Mozaffarian et al., 2010). This plant has many medicinal properties. In traditional medicine it is used as astringent and disinfectant and has an antileishmanial, antiparasitic, and antioxidant activities (Asghari et al., 2012). Verbenone, camphor, 1, 8-cineole, trans-verbenol, chrysanthenone, mesitylene, $\alpha$-pinene, acyclic monoterpenes, and monoterpene hydroperoxides are bioactive compounds extracted from this plant (Rustaiyan et al., 1987).

Drought stress is one of the major environmental factors limiting plant growth and productivity (Nazar et al., 2015). Drought stress induces the massive generation of reactive oxygen species (ROS). The accumulation of ROS inhibits normal function of lipids, proteins and DNA and finally reduces plant growth and development (Asada, 1999). Plants expose to drought display several morphological, physiological and molecular responses (Jiménez et al., 2013).

Salicylic acid (SA) is a phenolic compound that acts as important phytohormone. Several studies have demonstrated that SA participates in many physiological processes such as growth and development, respiration, stomatal aperture, senescence, seed germination, seedling growth and thermo-tolerance (Vicente and Plasencia, 2011). Moreover, many previous studies have shown that SA plays a role in many biotic and abiotic stresses (Vicente and Plasencia, 2011). This phytohormone can regulate responses to salinity (Idrees et al., 2012) and cold (Siboza et al., 2014), drought (Shen et al., 2014) and the toxicity of heavy metals (Tamás et al., 2015). Moreover, research has shown that SA levels and/or SA signaling played a positive regulatory role in plant response to polyethylene glycol (PEG)-simulated drought stress (He et al., 2014). It has been found that plants treated with SA generally exhibited more tolerance to water deficiency, SA alleviates the negative effects of drought stress on growth of
Zoysiagrass (Zoysia Willd.)(Chen ret al., 2014). Singh and Usha (2003) showed that SA increases dry weight and chlorophyll content in wheat seedlings in wheat seedlings under water stress. In addition, SA improves photosynthesis and growth of mustard under drought stress (Nazar et al., 2015). Foliar spray with SA positively affected physiological characteristics of fennel genotypes such as chlorophyll, carotenoid contents and soluble carbohydrate and increased drought tolerance (Askari and Ehsanzadeh, 2015).

Biotic and abiotic stresses induce the production of secondary metabolites, which are involved in the defense against harsh environmental conditions and enhance significantly the antioxidant activity of plant tissues. The phenylpropanoid pathway is one of the important pathways in plant secondary metabolite production including, phenolics and among them flavonoids (flavanols, anthocyanins and flavan-3-ols) compounds. These are also considered as antioxidant molecules because they are involved in scavenging of free radical (Pourcel et al., 2007). Key enzymes in the phenylpropanoid pathway are phenylalanine ammonia-lyase (PAL) and tyrosine ammonia-lyase (TAL). There has been few reports on activity of TAL in plants treated with SA under drought stress, while PAL activity has frequently been studied. Increase in PAL activity in wheat seedlings treated with SA under salinity stress leading to increase in phenolics and flavonoids and subsequently caused an improvement in antioxidant defense system (Saleh and Madany, 2015). On the other hand, Bandurska and Cies'lak (2013) showed a positive correlation between increase of SA content and PAL activity in leaves and roots of barley, under drought stress and UV-B radiation. Hence, there has been a positive relationship between the key enzymes activity in the phenylpropanoid pathway and production of flavonoids, among them anthocyanines and generally all phenolic compounds.

Artemisia aucheri has always been of great interest for botanical and pharmaceutical aspects. The effect of drought stress on physiological and biochemical responses in Artemisia aucheri has not been studied yet. Since, tissue culture technology is a rapid and fast method in assessment of 
physiological responses of the plant consequently; the present study was aimed to evaluate the mechanism of responses of $A$. aucheri to in vitro drought stress treated with salicylic acid (SA).

\section{MATERIALS AND METHODS}

\subsection{Plant material and growth conditions}

The Artemisia aucheri Boiss. plants were obtained from stock shoot culture of Department of Biology, University of Isfahan. Isfahan, Iran. Single node stem sections were propagated on MS (Murashige and Skoog., 1962) medium supplemented with $30 \mathrm{~g} / \mathrm{l}$ sucrose and $8 \mathrm{~g} / \mathrm{l}$ agar with adjusted $\mathrm{pH}$, to 5.8. Plants were grown in the culture room at $25 \pm 1{ }^{\circ} \mathrm{C}$ with $16 / 8 \mathrm{~h}$ photoperiod under $44 \mu \mathrm{mol}$ phot. $\mathrm{m}^{-2} \cdot \mathrm{s}^{-1}$ light.

In treatment experiment SA was added to the media at following concentrations: $0,0.01$ and $0.1 \mathrm{mM}$. For drought stress treatments, PEG (polyethylene glycol, MW 6000) was used in 0, $2 \%$ and $4 \%(\mathrm{w} / \mathrm{v})$ concentrations. PEG was added to MS medium according to diffusion based method described by Girma and Kreig (199). Based on the Factorial Design of the experiments, three explants were cultured per jar (each jar was one replicate) and after 4 weeks, explants were harvested for analysis of different physiological and biochemical parameters. Plants were grown in three different medium, 1) medium without SA and PEG (control), 2) medium with SA and PEG separately, 3) medium with combination of PEG and SA.

\subsection{Growth measurement}

Fresh mass was measured directly after harvesting of plants and dry mass was measured after drying the plant materials at $70{ }^{\circ} \mathrm{C}$ for 24 hours. Shoot relative water content was measured according to Weatherly (1950) as described by Bandurska (2000) and it was calculated by the following formula: $\mathrm{RWC}=[($ fresh mass - dry mass $) /($ fresh matter at full turgor - dry mass)] $\times 100$. TW is turgid mass after saturating the fresh sample with water for $4 \mathrm{~h}$.

\subsection{Determination of chlorophyll and carotenoid content}

For photosynthetic pigment measurements, leaves $(0.1 \mathrm{~g})$ of the plants were grounded in $80 \%$ cold acetone and centrifuged at $5000 \mathrm{~g}$ for $10 \mathrm{~min}$. The absorbance of the purified chlorophyll samples were measured at 470, 646, and $663 \mathrm{~nm}$ (Shimadzu, Japan). Chlorophylls and carotenoid contents were calculated according to Lichtenthaler and Wellburn (1983).

\subsection{Soluble carbohydrates and storage polysaccharides}

Water soluble carbohydrates were determined based on the phenol-sulfuric-acid method (Dubois et al., 1956). To prepare carbohydrate extract, $10 \mathrm{mg}$ of dry leaf and stem was homogenized with $10 \mathrm{ml}$ deionized water. The samples were centrifuged and supernatant used to determine soluble sugars. Sample $(0.5 \mathrm{ml})$ was mixed with $0.5 \mathrm{ml}$ of phenol $(5 \%)$ and then mixed with $2.5 \mathrm{ml}$ sulfuric acid $(96 \%)$. The samples were vortexed slowly for $30 \mathrm{~min}$ then soluble carbohydrates were measured at $490 \mathrm{~nm}$. To determine the storage polysaccharides, sediment of carbohydrate extract was weighted and again homogenized with deionized water and boiled for one hour. Finally, storage polysaccharides were measured at $490 \mathrm{~nm}$.

\subsection{Anthocyanin content}

Total anthocyanins were extracted and determined based on the method described by Laby et al (Laby et al., 2000) with minor modifications. Leaves $(0.1 \mathrm{~g})$ were grounded in 99:1 methanol: $\mathrm{HCl}(\mathrm{v} / \mathrm{v})$ and incubated at $4^{\circ} \mathrm{C}$ for $16 \mathrm{~h}$. Then, samples were centrifuged at $4^{\circ} \mathrm{C}$ and the absorbance of the supernatants were measured at 530 and $657 \mathrm{~nm}$. Total anthocyanin content was expressed as $\mathrm{A}_{530} \mathrm{~g}$ ${ }^{1} \mathrm{FW}$.

\subsection{Phenolic content}

The Folin-Denis method was applied to estimate total phenols contents in the supernatant (Singleton et al., 1999). Leaf samples $(0.1 \mathrm{~g})$ were homogenized with $10 \mathrm{ml}$ of methanol $80 \%$. The homogenates were centrifuged at $12,000 \mathrm{~g}$ for 10 min then $1 / 5 \mathrm{ml}$ Folin-Ciocalteu reagent $(10 \%)$ and $1 \mathrm{ml} \mathrm{Na} \mathrm{CO}_{3}(7.5 \%)$ was added to $0.5 \mathrm{ml}$ methanol extract. The absorbance of samples was measured at $760 \mathrm{~nm}$. The total phenolic 
compounds were calculated from the standard curve, using gallic acid as a standard and expressed as mg gallic acid (Sigma, USA) $\mathrm{g}^{-1} \mathrm{FW}$.

\subsection{Flavonoid content}

To determine the flavonoid content, $0.1 \mathrm{~g}$ of fresh leaf tissue homogenized in $80 \%$ methanol and centrifuged at $10000 \mathrm{~g}$ for $10 \mathrm{~min}$. The reaction mixture containing $0.2 \mathrm{ml}$ of $80 \%$ methanol, $0.2 \mathrm{ml}$ of aluminum chloride $(10 \%), 0.2 \mathrm{ml}$ of sodium acetate and $0.1 \mathrm{ml}$ leaf extract. After 30 min, the absorbance of the samples was measured at $415 \mathrm{~nm}$. The quercetin (Sigma, USA) was used for the standard curve and results were expressed as $\mathrm{mg} \mathrm{g}^{-1}$ FW (Chang et al., 2002).

\subsection{PAL and TAL assay}

To estimate the PAL and TAL activity, leaf samples $(300 \mathrm{mg})$ were grounded in a mortar at $4{ }^{\circ} \mathrm{C}$ with $4 \mathrm{~mL}$ buffer $(50 \mathrm{mmol} / 1$ Tris $\mathrm{pH} 8.5$, $14.4 \mathrm{mmol} / \mathrm{l}$ 2-mercaptoethanol, $5 \quad \% \quad \mathrm{w} / \mathrm{v}$ polyvinylpolypyrrorolidone) and was centrifuged at $6,000 \mathrm{~g}$ for $10 \mathrm{~min}$ at $4{ }^{\circ} \mathrm{C}$. The supernatant was collected and centrifuged at 10,000 g for $10 \mathrm{~min}$ at $4{ }^{\circ} \mathrm{C}$ and was used to assay enzyme activity. The total protein concentration in soluble enzyme extracts was determined using the Bradford (1976) method. The reaction mixture contained $500 \mu \mathrm{mol}$ of Tris- $\mathrm{HCl}$ buffer $(\mathrm{pH} 8), 100 \mu$ l of enzyme extraction and either $6 \mu \mathrm{mol}$ of L-phenylalanine for measuring PAL activity (EC 4.3.1.5) or $5.5 \mu \mathrm{mol}$ of L-tyrosine (Sigma, USA) for measuring TAL activity (EC 4.3.1). After $60 \mathrm{~min}$ at $40^{\circ} \mathrm{C}$, the reaction was stopped by the addition of $0.05 \mathrm{ml}$
$5 \mathrm{~N} \mathrm{HCl}$. The amounts of trans-cinnamic and pcoumaric acids were determined by measuring absorbance at 290 and $333 \mathrm{~nm}$, respectively. The PAL and TAL activities were expressed as nmoles (cinnamic or coumaric acid) $\mathrm{h}^{-1} \mathrm{mg}^{-1}$ protein (Beaudoin-Eagan and Thorpe., 1985).

\subsection{Total antioxidant capacity}

Leaf samples $(0.1 \mathrm{~g})$ were homogenized with $80 \%$ methanol in cold mortar and pestle and centrifuged at $18000 \mathrm{~g}$ for $10 \mathrm{~min}$. The extrications were used to measure total antioxidant capacity by ferric reducing antioxidant power (FRAP) method (Benzie and Strain., 1996) This method is based on the reduction of ferric tripyridyltriazine (FeIII_TPTZ) complex to ferrous (FeII) form that makes blue color with maximum absorption at $593 \mathrm{~nm}$. FRAP working solution consisted with $25 \mathrm{ml}$ of acetate buffer (300 mM, pH 3.6), $2.5 \mathrm{ml}$ TPTZ (Sigma, USA) solution (10 Mm in $40 \mathrm{mM}$ $\mathrm{HCl})$ and $2.5 \mathrm{ml}$ of $\mathrm{FeCl}_{3}(20 \mathrm{mM})$ solution. $1.5 \mathrm{ml}$ of FRAP reagent was added to $50 \mu$ plant extract and mixed well. The absorbance was measured at $593 \mathrm{~nm}$ after $5 \mathrm{~min}$. Standard curve was prepared using the similar procedure with ascorbic acid as standard.

\subsection{Statistical analysis}

All experiments were carried out with at least three replicates and the results were expressed as mean \pm standard deviation (SD). ANOVA was performe to determine the significance of differences between means by Duncan's test $(p<0.05)$.

\section{RESULTS AND DISCUSSION}

Plants have developed mechanisms to alleviate negative effects of drought stress to increase their chance for survival. SA as a phytohormone can be effective in modulating physiological and biochemical responses leading to adaptation of plants to unfavorable environments such as drought stress (Kang et al., 2013; Nazar et al., 2015).

The obtained data indicate that fresh and dry mass of control (without SA and PEG) plants supplemented with $0.01 \mathrm{mM}$ SA were increased significantly, while fresh and dry mass of $0.1 \mathrm{mM}$
SA treated plants was comparable to untreated controls. Fresh mass decreased dramatically by $57 \%$ and $76 \%$ when control plant treated with 2 and $4 \%$ PEG respectively, and 2 and $4 \%$ PEG decreased dry mass by $53 \%$ and $72.5 \%$ comparing to the control respectively. Application of SA (0.01 and $0.1 \mathrm{mM}$ SA) significantly improved both parameters when compared to PEG treated controls without SA treatment. The maximum increase of fresh and dry mass was observed at $0.01 \mathrm{mM} \mathrm{SA} \mathrm{(56} \mathrm{and} 59 \%$ in fresh mass under $2 \%$ PEG and 51.5 and $43 \%$ in dry mass under $4 \%$ PEG) (Figure. 1). Furthermore, as 
it is shown in the Figure. 2, SA $(0.01 \mathrm{mM})$ increased photosynthetic pigments in control plant without PEG treatment. On the other hand, treatment of A.aucheri with PEG reduced chlorophyll and carotenoid contents compared with untreated plants. Under $2 \%$ PEG treatment, a similar increase in total chlorophyll and carotenoid concentrations was measured when plants were treated with 0.01 and $0.1 \mathrm{mM} \mathrm{SA}$, respectively. However, the effect of SA treatment on pigment contents was insignificant when plants were pretreated with $4 \%$ PEG. The results in our study are in agreement with those reported by other authors. It is known that exogenous SA application enhanced the growth and photosynthetic pigments in several plant species treated under water stress such as wheat (Singh and Usha, 2003), Nigella sativa (Kabiri et al., 2014), Zoysiagrass (Chen et al., 2014), mustard (Nazar et al., 2015). Increase in fresh and dry mass by SA application under drought stress can be related to the positive effect of SA on photosynthetic pigments which led to the improvement in growth. In other words, the low water availability reduces photosynthesis, resulting in a reduction of carbohydrate accumulation, limiting overall plant growth (Chaves and Oliveira, 2004). In the control plant, the RWC remained at similar levels when plant was treared with SA. RWC decreased progressively under water deficit as compared with control plants, both concentration of salicylic acid increased RWC as compared to plant without application of SA under drought conditions (Fig. 3). Similar result were observed in pot experiments with barley (Habibi, 2012) and Arabidopsis (Khokon et al., 2011). It was suggested that the observed increase in RWC may be due to SA induced stomatal closure which reduces water loss. However, these results cannot be directly compared to our observations, since in vitro cultivated plants have quite unique water balance regulation. Their control of transpiration is poor due to very thin cuticle and malfunctioning of the stomata (Sutter, 1988). In this respect the results of our study only prove the involment of SA in plant response to drought, but have limited direct ecological relevance.
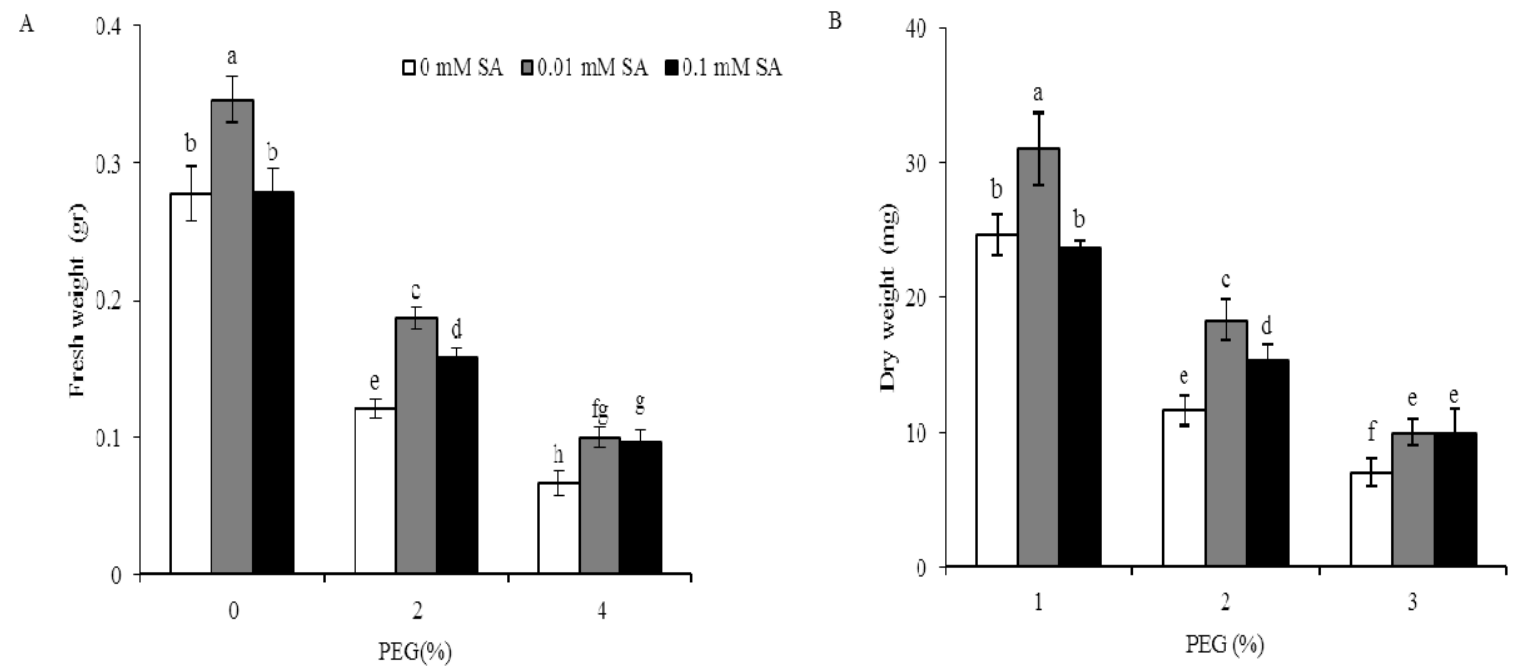

Figure 1: Effects of SA and PEG on (A) fresh and (B) dry mass of Artemisia aucheri. Data are means \pm SD. Different letters indicate significant differences $(P<0.05)$ based on Duncan's test. 

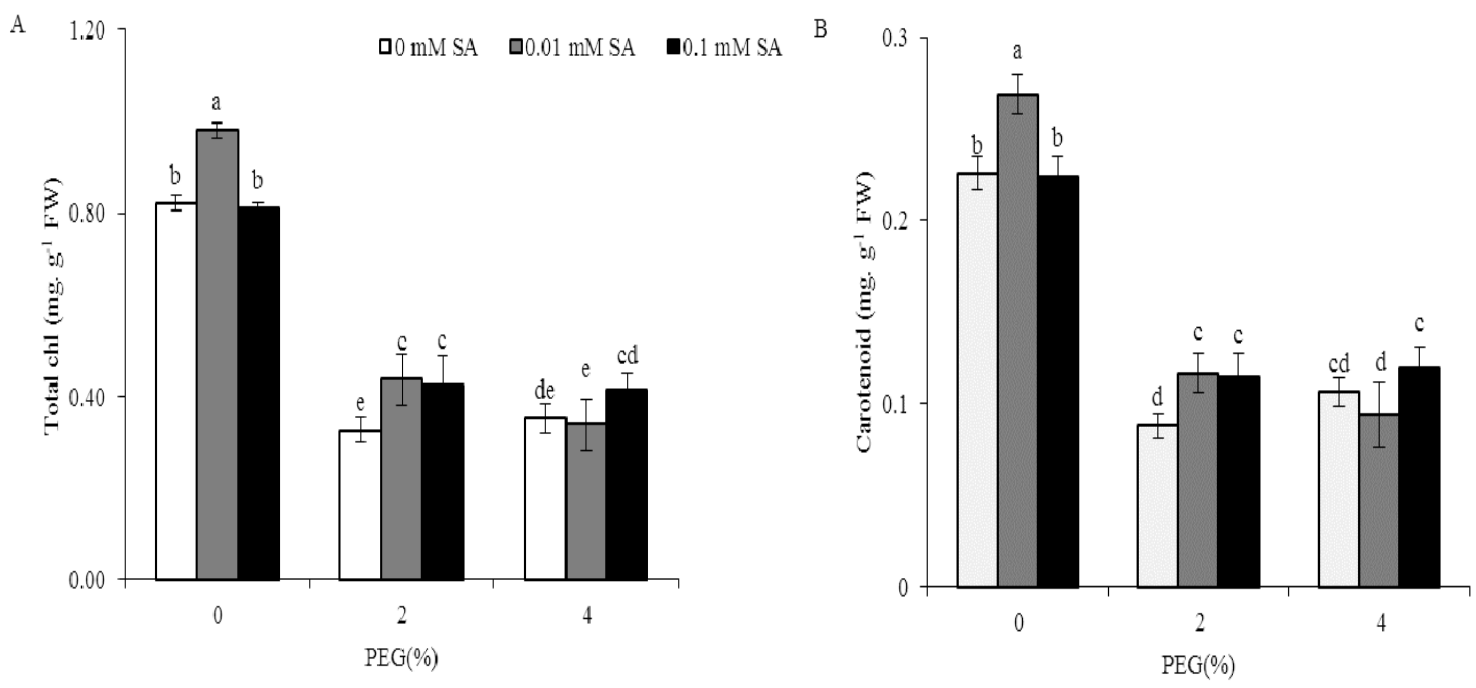

Figure 2: Effects of SA and PEG on (A) chlorophyll and (B) carotenoid of Artemisia aucheri. Data are means \pm SD. Different letters indicate significant differences $(P<0.05)$ based on Duncan's test.

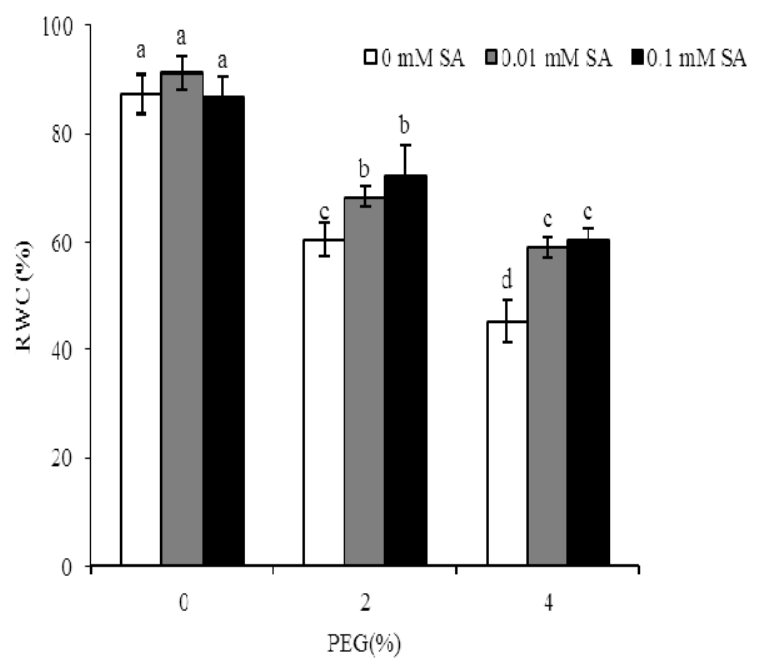

Figure 3: Effects of SA and PEG on relative water content (RWC) of Artemisia aucheri. Data are means \pm SD. Different letters indicate significant differences $(P<0.05)$ based on Duncan's test.

Changes of carbohydrate and storage polysaccharides are presented in Figure 4. Drought stress ( 2 and $4 \%$ PEG) declined the content of storage polysaccharides compared with untreated plants, and maximum decreased was observed at $4 \%$ PEG. However it had no significant effect on soluble carbohydrates. Under $2 \%$ and $4 \%$ PEG, SA treatments decreased storage polysaccharides in the same manner (Figure. 4B), while soluble carbohydrates were increased (Figure. 4A).
Moreover, both forms of carbohydrates in control plant were enhanced with $0.01 \mathrm{mM}$ SA treatment. Soluble carbohydrates act as compatible solutes which support osmoregulation and are the main source of energy when plants are exposed to unfavorable environmental conditions (Patakas and Noitsakis, 2001). Increase of total soluble carbohydrates and storage polysaccharide content with $0.01 \mathrm{mM} \mathrm{SA}$ in control plants reflects stimulating role of SA in plant growth. 
Interestingly, when SA treated plants have been exposed to drought stress, it has shown reverse trends in soluble sugars and polysaccharide contents as a result of graduate increase in SA treatment. It seemed that SA has facilitated conversion of polysaccharide to soluble carbohydrates and resulted in osmotic adjustment and resistance under drought. Accumulation of compatible solution is as an effective response to dehydration (Patakas and Noitsakis, 2001).
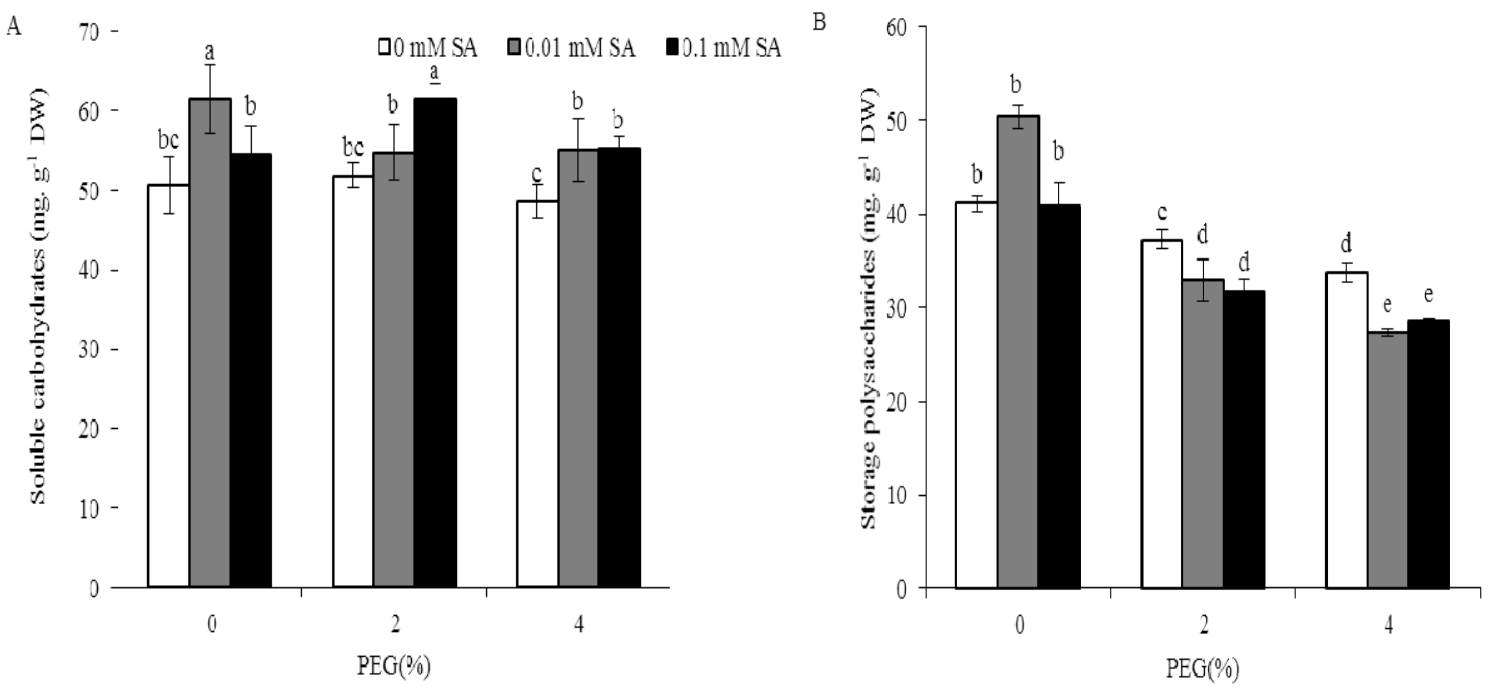

Figure 4: Effects of SA and PEG on (A) soluble carbohydrates and (B) storage polysaccharides content of Artemisia aucheri. Data are means \pm SD. Different letters indicate significant differences $(P<0.05)$ based on Duncan's test.

According to our results, SA as a single treatment is able to increase phenolic compounds. Drought stress significantly elevated total phenolic contents compared with untreated plants. Moreover, both concentrations of SA $(0.01$ and $0.1 \mathrm{mM})$ increased the total phenol in $2 \%$ PEG treated plants while SA with $0.1 \mathrm{mM}$ increased phenol content in $4 \%$ PEG (Figure. 5A). Drought stress induced by PEG had no significant effect on flavonoid levels compared with untreated plants. SA treatments ( 0.01 and $0.1 \mathrm{mM} \mathrm{SA})$ were remarkably effective on increasing of flavonoid content under $4 \%$ PEG. In addition, flavonoid content was enhanced in response to $0.1 \mathrm{mM}$ SA compared to control plants (Figure. 5B). Application of SA in the culture medium increased anthocyanin content in both PEG-treated and untreated plants. SA treatments in SA $(0.1 \mathrm{Mm})+$ PEG $(2 \%)$ and SA $(0.01 \mathrm{mM})+$ PEG (4 \%) showed significant difference compared with the same PEG levels without SA (Figure. 5C). 


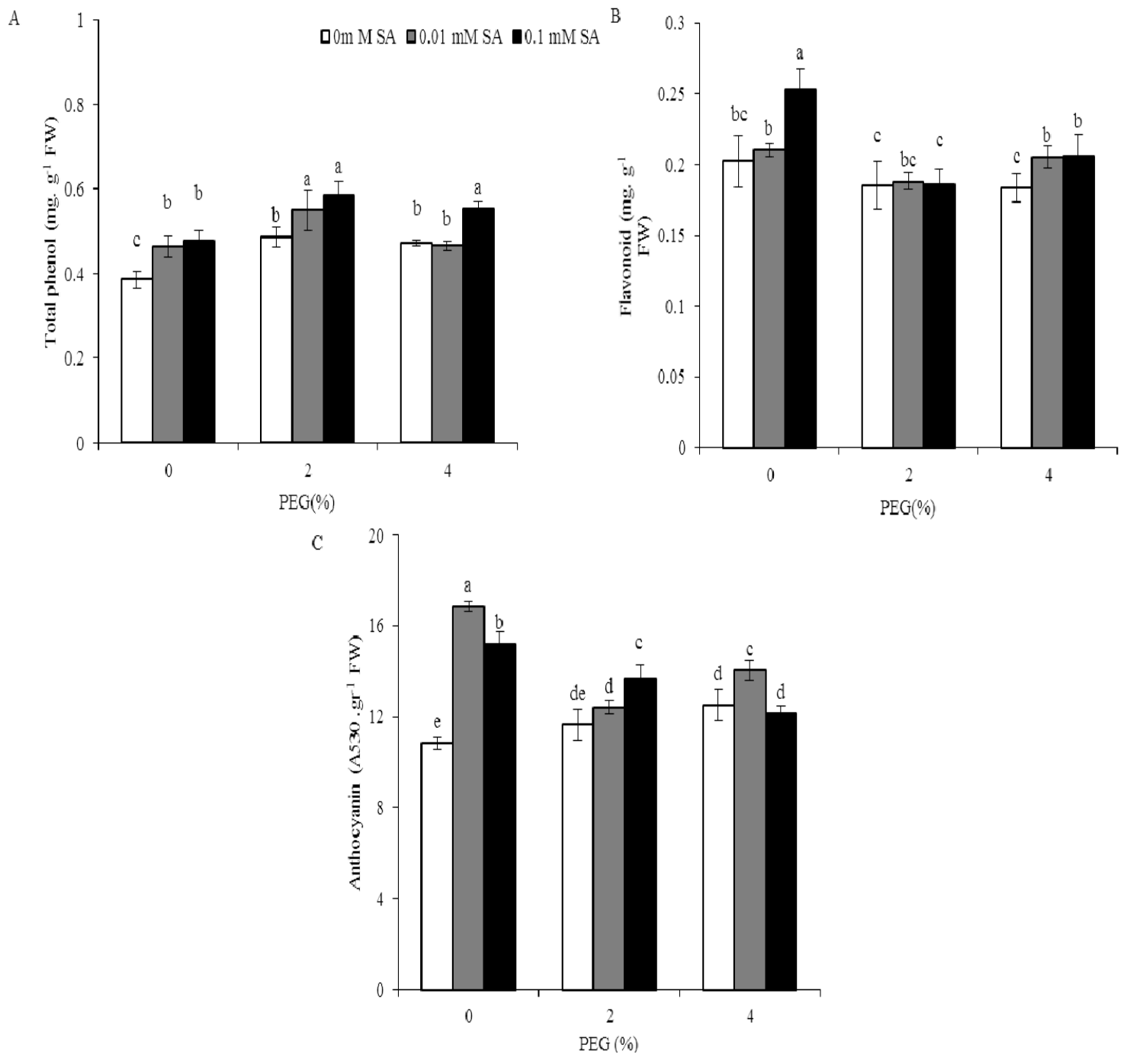

Figure 5: Effects of SA and PEG on (A) total phenol and (B) flavonoid and (C) anthocyanin content of Artemisia aucheri. Data are means \pm SD. Different letters indicate significant differences $(P<0.05)$ based on Duncan's test.

PAL and TAL are two key enzymes in the phenylpropanoid pathway that catalyse the conversion of L-phenylalanine and L-tyrosine to trans-cinnamic acid and p-coumaric acids, respectively (Schroeder et al., 2008). Drought stress induced by PEG in combination with SA treatments remarkably enhanced PAL and TAL activity (Fig. 6). Notably, the increase of PAL activity in SA $(0.01$ and $0.1 \mathrm{mM})$ treated plants was also observed. The plants treated with $2 \%$ and $4 \%$ PEG showed an increase in PAL activity in $0.1 \mathrm{mM}$ SA (Figure. 6A). Moreover, SA $(0.1 \mathrm{mM})$ elevated TAL activity under $2 \%$ PEG treatment, while SA treatments had no significant effect on TAL activity when plants were exposed to $4 \%$ PEG (Figure. 6B). Our results are in agreement with the previous findings, that the increase in total phenolic content, such as phenol and flavonoids is accompanied by the induction of PAL and TAL activities that are involved in the defense system against biotic and abiotic stresses ( $\mathrm{S}^{\prime}$ wieca, 2015). The increase in level of anthocyanin, flavonoid and total phenol content by SA treatment was associated with TAL and PAL activity. Similar observation was reported by Dogbo et al (2012). They also showed exogenous salicylic acid induced PAL and TAL activity in cassava cell suspensions. Furthermore, elicitation using hydrogen peroxide in lentil sprouts enhanced PAL and TAL activity and subsequently elevated phenolic levels (S'wieca, 2015). Several studies have demonstrated that the production of ROS 
especially hydrogen peroxide is induced by SA (Miura and Tada, 2013). Although under PEG treatments flavonoid contents did not change significantly, but anthocyanin as a phenolic component and total phenol as well as TAL and PAL activity elevated significantly. Similar findings were observed in the drought-tolerant barley cultivars under drought and salinity stress which confirms the role of antioxidant activity in this components and enzymes (Ahmed et al.,
2015). Generally, our results showed that combination of SA with PEG has improved phenolic compounds production and two key enzymes of phenolic biosynthesis pathway. Kabiri et al (2014) reported that SA increased total phenol, anthocyanin, and flavonoid content under drought stress and drought damages were reduced. In fact SA could induce activity of PAL and TAL activity and consequently phenolic compounds were increased (Bandurska and Cie'slak, 2013).
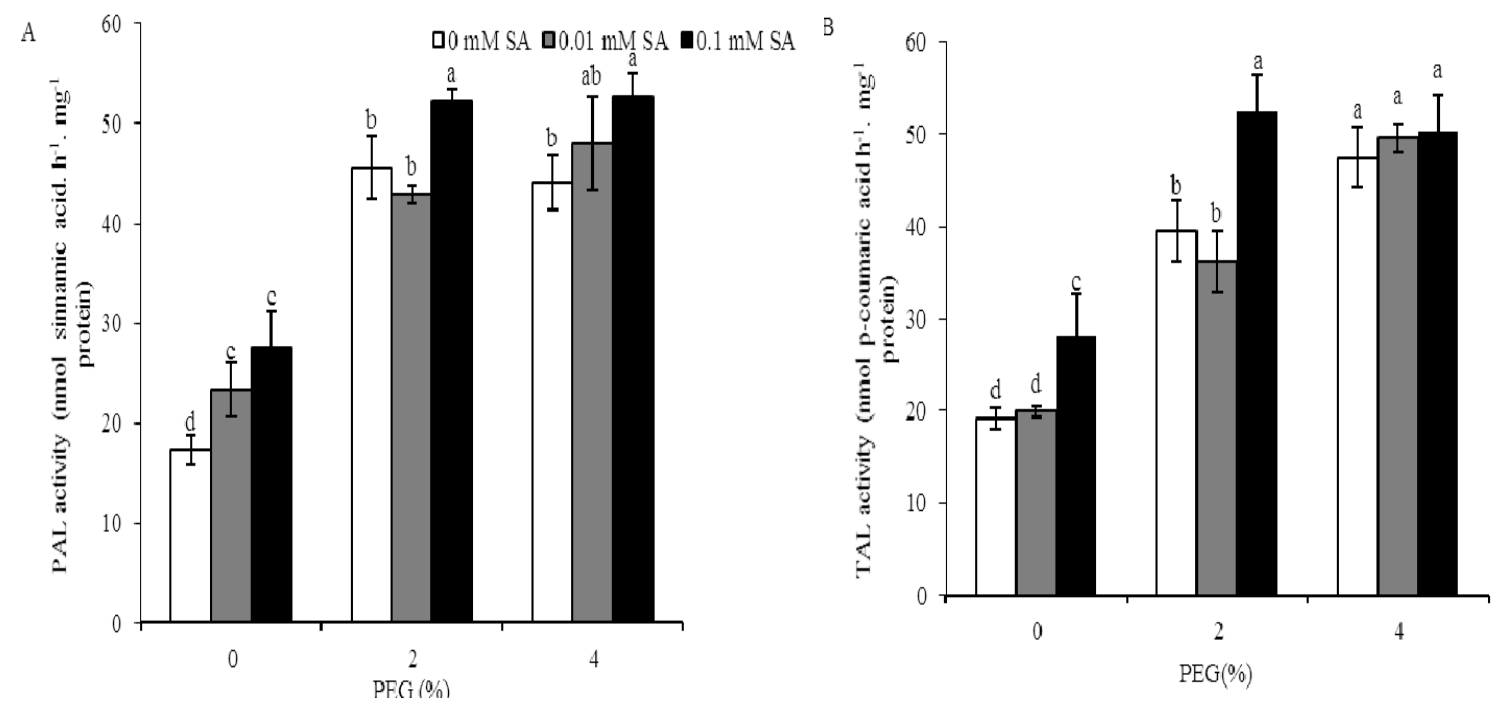

Figure 6: Effects of SA and PEG on (A) PAL and (B) TAL activity of Artemisia aucheri. Data are means \pm SD. Different letters indicate significant differences $(P<0.05)$ based on Duncan's test.

Plants subjected to drought stress demonstrated higher total antioxidant capacity when exposed to higher PEG concentration. Total antioxidant capacity increased significantly in $0.01 \mathrm{mM} \mathrm{SA}$ treated controls and $0.01 \mathrm{mM} \mathrm{SA}+2 \%$ PEG treated plants, the last showing a maximum level of antioxidant capacity. Moreover, plants subjected to drought and $0.1 \mathrm{mM}$ SA showed higher total antioxidant capacity compared to the same PEG level without SA (Fig. 7). It seemed that antioxidant property of phenolic compounds increased drought tolerance of $A$. aucheri as previously reported in barley (Saleh and Madany, 2015) and olive (Hashempour et al., 2014). 


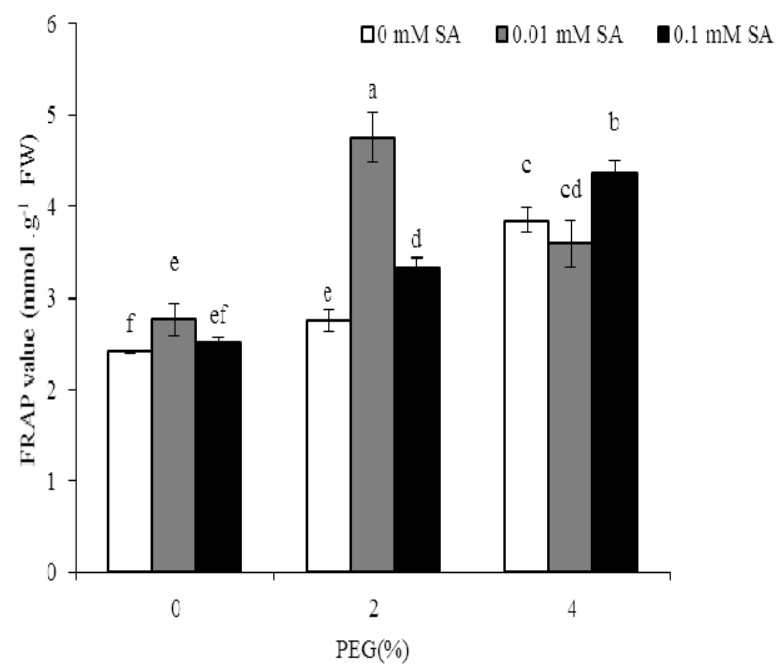

Figure 7: Effects of SA and PEG on total antioxidant capacity of Artemisia aucheri. Data are means \pm SD. Different letters indicate significant differences $(P<0.05)$ based on Duncan's test.

\section{CONCLUSION}

Based on the present data, SA treatment alleviates drought stress induced by PEG in A. aucheri plants. This enhanced tolerance could be related to the improvement of antioxidant capacity via increase in PAL and TAL activities and the subsequent increase in anthocyanin, flavonoid and total phenol content. Furthermore, SA improves osmotic adjustment by conversion of storage polysaccharide to soluble carbohydrate.

\section{ACKNOWLEDGEMENTS}

Authors are grateful to the University of Isfahan and Plant Stress Center of Excellence (PSCE) for their support.

\section{REFERENCES}

Ahmed I.M., Nadira U.K, Bibi N., Cao F., He X., Zhang G., Wu F. 2015. Secondary metabolism and antioxidants are involved in the tolerance to drought and salinity, separately and combined, in Tibetan wild barley. Environmental and Experimental Botany, 111:1-12. Doi: 10.1016/j.envexpbot.2014.10.003

Asada K. 1999. The water-water cycle in chloroplasts: scavenging of active oxygens and dissipation of excess photons. Annual Review of Plant Biology, 150: 601-639.

10.1146/annurev.arplant.50.1.601

Asghari G., Jalali M., Sadoughi E. 2012. Antimicrobial activity and chemical composition of essential oil from the seeds of Artemisia aucheri Boiss. Jundishapur Journal of Natural Pharmaceutical Products, 7: 11-15. Doi: 10.17795/jjnpp-3530

Askari E., Ehsanzadeh P. 2015. Drought stress mitigation by foliar application of salicylic acid and their interactive effects on physiological characteristics of fennel (Foeniculum vulgare Mill.) genotypes. Acta Physiologiae Plantarum, 37:2-14. Doi: 10.1007/s11738-014-1762-y

Bandurska H. 2000. Does proline accumulated in leaves of water deficit stressed barley plants confine cell membrane injury? I. Free proline accumulation and membrane injury index in drought and osmotically 
stressed plants. Acta Physiologiae Plantarum, 22: 409-415. Doi: 10.1007/s11738-000-0081-7

Bandurska H., Cie' slak M. 2013. The interactive effect of water deficit and UV-B radiation on salicylic acid accumulation in barley roots and leaves. Environmental and Experimental Botany, 94:9-18. Doi: $10.1016 /$ j.envexpbot.2012.03.001

Beaudoin-Eagan L.D., Thorpe T.A. 1985. Tyrosine and phenylalanine ammonia lyase activities during shoot initiation in tobacco callus cultures. Plant Physiology, 78: 438-441. Doi: 10.1104/pp.78.3.438

Benzie F., Strain J. 1996. The ferric reducing ability of plasma (FARP) as a measure of antioxidant power: the FARP assay. Analytical Biochemistry, 239: 7076. Doi: 10.1006/abio.1996.0292

Bradford M.M. 1976. A rapid and sensitive method for the quantification of microgram quantities of protein utilizing the principle of protein-dye binding. Analytical Biochemistry, 72: 1151-1154. Doi: 10.1016/0003-2697(76)90527-3

Chang C.C., Yang M.H., Wen H.M., Chern J.C. 2002. Estimation of total flavonoid content in propolis by two complementary colorimetric methods. Journal of Food and Drug Analysis, 10: 178-182.

Chaves M.M., Oliveira M.M. 2004. Mechanisms underlying plant resilience to water deficits: prospects for water-saving agriculture. Journal of Experimental Botany, 55: 2365-2384. Doi: $10.1093 / \mathrm{jxb} / \mathrm{erh} 269$

Chen Z.L., Li X.M., Zhang L.H. 2014. Effect of salicylic acid pretreatment on drought stress responses of zoysiagrass (Zoysia japonica). Russian Journal of Plant Physiology, 61: 619-625. Doi: 10.1134/S1021443714050057

Dogbo D.O., Gogbeu S.J., Nzue B., Yao K.A., Zohouri G.P., Mamyrbekovabekro J.A., Bekro Y.A. 2012. Comparative activities of phenylalanine ammonialyase and tyrosine ammonia-lyase and phenolic compounds accumulated in cassava elicited cell. African Crop Science Journal, 20: 85-94.

Dubois M., Gilles K.A., Hamilton J.K., Reberts P.A., Smith F. 1956. Colorimetric method for determination of sugar and related substrates. Analytical Chemistry, 28: 350-356. Doi: 10.1021/ac60111a017

Girma F.S., Kreig D.R. 1992. Osmotic adjustment in Sorghum. Plant Physiology 99: 577-582. Doi: 10.1104/pp.99.2.577

Habibi G. 2012. Exogenous salicylic acid alleviates oxidative damage of barley plants under drought stress. Acta Biologica Szegediensis, 56: 57-63.
Hashempour A., Ghasemnezhad M., Fotouhi Ghazvini R., Sohani M.M. 2014. The physiological and biochemical responses to freezing stress of olive plants treated with salicylic acid. Russian Journal of Plant Physiology, 61: 443-450. Doi: 10.1134/S1021443714040098

He Q., Zhao S., Ma Q., Zhang Y., Huang L., Li G., Hao L. 2014. Endogenous salicylic acid levels and signaling positively regulate Arabidopsis response to polyethylene glycol-simulated drought stress. Journal of Plant Growth Regulation, 33: 871-880. Doi: 10.1007/s00344-014-9438-9

Idrees M., Naeem M., Khan M.N., Aftab T., Khan M.M.A., Moinuddin. 2012. Alleviation of salt stress in lemongrass by salicylic acid. Protoplasma, 249: 709-720. Doi: 10.1007/s00709-011-0314-1

Jiménez S., Dridi D., Gutiérrez D., Moret D., Irigoyen J.J., Moreno M.A., Gogorcena Y. 2013. Physiological, biochemical and molecular responses in four Prunus rootstocks submitted to drought stress. Tree Physiology, 33: 1061-1075. Doi: 10.1093/treephys/tpt074

Kabiri R., Nasibi F., Farahbakhsh H. 2014. Effect of exogenous salicylic acid on some physiological parameters and alleviation of drought stress in Nigella sativa plant under hydroponic culture. Plant Protection Science, 50: 43-51.

Kang G.Z., Li G.Z., Liu G.Q., Xu W., Peng X.Q., Wang C.Y., Zhu Y.J, Guo T.C. 2013. Exogenous salicylic acid enhances wheat drought tolerance by influence on the expression of genes related to ascorbateglutathione cycle. Biologia Plantarum, 57: 718-724. Doi: $10.1007 / \mathrm{s} 10535-013-0335-\mathrm{z}$

Khokon M.A.R., Okuhama E., Hossain M.A., Uraji S.M.M., Nakamura Y., Murata Y. 2011. Involvement of extracellular oxidative burst in salicylic acid-induced stomatal closure in Arabidopsis. Plant Cell and Eenvironment. 34: 434443. Doi: 10.1111/j.1365-3040.2010.02253.x

Laby R.J., Kincaid M.S., Kim D., Gibson S.I. 2000. The Arabidopsis sugar-insensitive mutants sis4 and sis5 are defective in abscisic acid synthesis and response. The Plant Journal, 23: 587-596. Doi: 10.1046/j.1365-313x.2000.00833.x

Lichtenthaler H., Wellburn A. 1983. Determinations of total carotenoids and chlorophylls a and b of leaf extracts in different solvents. Biochemical Society Transactions, 11: 591-592. Doi: $10.1042 / \mathrm{bst} 0110591$

Miura K., Tada Y. 2014. Regulation of water, salinity, and cold stress responses by salicylic acid. Frontier in Plant Science, 5: 1-12. Doi: 10.3389/fpls.2014.00004

Acta agriculturae Slovenica, 107 - 2, september 2016 
Mozaffarian V. 2010. Flora of Iran (Composite). Tehran, Iran: Iranian Research Institute of Forest and Rangeland Press.

Murashige T., Skoog F. 1962. A revised medium for rapid growth and bioassays with tobacco tissue cultures. Physiologia Plantarum, 15: 473-479. Doi: 10.1111/j.1399-3054.1962.tb08052.x

Nazar R., Umar S., Khan N.A., Sareer O. 2015. Salicylic acid supplementation improves photosynthesis and growth in mustard through changes in proline accumulation and ethylene formation under drought stress. South African Journal of Botany, 98: 84-94. Doi: 10.1016/j.sajb.2015.02.005

Patakas A., Noitsakis B. 2001. Leaf age effects on solute accumulation in water-stressed grapevines. Journal of Plant Physiology, 158: 63-69. Doi: 10.1078/0176-1617-00003

Pinhero R.G., Rao M.V., Palyath G., Murr D.P., Fletcher R.A. 1997. Changes in the activities of antioxidant enzymes and their relationship to genetic and paclobutrazol induced chilling tolerance of maize seedlings. Plant Physiology, 114: 695-704.

Pourcel L., Routaboul J.M., Cheynier V., Lepiniec L., Debeaujon I. 2007. Flavonoid oxidation in plants: from biochemical properties to physiological functions. Trends Plant science, 12: 29-36. Doi: 10.1016/j.tplants.2006.11.006

Rustaiyan A., Bamoniri A., Raffatrad M., Jakupovic J., Bohlman F. 1987. Eudesmanederivatives and highly oxygenatedmonoterpenes from Iranian Artemisia species. Phytochemistry, 26: 2307-2310. Doi: 10.1016/S0031-9422(00)84708-1

Saleh A.M., Madany M.M.Y. 2015. Coumarin pretreatment alleviates salinity stress in wheat seedlings. Plant Physiology and Biochemistry, 88: 27-35. Doi: 10.1016/j.plaphy.2015.01.005

Schroeder A.C., Kumaran S., Hicks L.M., Cahoon R.E., Halls C., Yu O., Jez J.M. 2008. Contributions of conserved serine and tyrosine residues to catalysis, ligand binding, and cofactor processing in the active site of tyrosine ammonia lyase. Phytochemistry, 69: 1496-1506. Doi: 10.1016/j.phytochem.2008.02.007
Shen C., Hu Y., Du X., Li T., Tang H., Wu J. 2014. Salicylic acid induces physiological and biochemical changes in Torreya grandis cv. Merrillii seedlings under drought stress. Trees, 28: 961-970. Doi: 10.1007/s00468-014-1009-y

Siboza X.I., Bertling I., Odindo A.O. 2014. Salicylic acid and methyl jasmonate improve chilling tolerance in cold-stored lemon fruit (Citrus limon). Journal of Plant Physiology, 171: 1722-1731. Doi: 10.1016/j.jplph.2014.05.012

Singh B., Usha K. 2003. Salicylic acid induced physiological and biochemical changes in wheat seedlings under water stress. Plant Growth Regulation, 39:137-141. Doi: 10.1023/A:1022556103536

Singleton V.L., Orthofer R., Lamuela-Raventos R.M. 1999. Analysis of total phenols and other oxidation substrates and antioxidants by means of folinciocalteu reagent. Methods in Enzymology, 299: 152-178. Doi: 10.1016/S0076-6879(99)99017-1

Sutter E., G., 1988. Stomatal and cuticular water loss from apple, cherry, and sweetgum plants after removal from in vitro culture.- Journal of the American Society for Horticultural Science 113:234-238

S'wieca M. 2015. Production of ready-to-eat lentil sprouts with improved antioxidant capacity: optimization of elicitation conditions with hydrogen peroxide. Food Chemistry, 180: 219-226

Tamás L., Mistrík I., Alemayehu A., Zelinová V., Bo`cová B., Huttová J. 2015. Salicylic acid alleviates cadmium-induced stress responses through the inhibition of Cd-induced auxinmediated reactive oxygen species production in barley root tips. Journal of Plant Physiology, 73:18. Doi: 10.1016/j.jplph.2014.08.018

Vicente M.R.S., Plasencia J. 2011. Salicylic acid beyond defence: its role in plant growth and development. Journal of Experimental Botany, 62: 3321-3338. Doi: 10.1093/jxb/err031

Weatherly P.E. 1950. Studies in water relation of cotton plants. I. The measurement of water deficits in leaves. New Phytologist, 49: 81-97. Doi: 10.1111/j.1469-8137.1950.tb05146.x 